\title{
New ruralities in the context of global economic and environmental change - are small-scale farmers bound to disappear?
}

\author{
T. Rauch \\ Free University of Berlin, Berlin, Germany \\ Correspondence to: T. Rauch (theorauch@gmx.de)
}

Received: 29 May 2013 - Revised: 22 August 2013 - Accepted: 21 November 2013 - Published: 11 December 2014

\begin{abstract}
While development practicians tend to celebrate the renaissance of rural development, critical scholars are concerned about the increasing commoditisation of rural resources in the global South coinciding with the end of the peasant mode of production. The new debate on the future of rurality is associated with trends such as price hikes for rural products, climate change, food crisis, institutional change and multi-local livelihood systems.

Usually, these trends are analysed from different perspectives. While many geographers look at it from a livelihood systems perspective, political economists focus on global food markets, whereas climate change research considers rural dynamics predominantly as a response to climate. This article argues that the new rural dynamics can only be understood by taking a holistic multi-dimensional approach which puts those different perspectives into context, rather than arguing which is more relevant. Based on a multi-dimensional analytical framework, the article investigates economic, environmental, social and political-institutional dynamics behind the actual trends.
\end{abstract}

\section{New global dynamics: opportunity or threat for rural people in the global South?}

Some critical analysts (e.g. Van der Ploeg, 2010; Hoering, 2011) see clear indications for the end of the still dominant peasant mode of production in the global South, since it is being threatened by land grabbers, financial markets, food speculators, climate change and dependency on genetically manipulated crops. On top of that, they anticipate the emergence of more severe food crises and accelerated environmental destruction as a result of the increasing demand for agro-based fuel and meat.

Representatives of development policy agencies, in contrast, tend to celebrate the renaissance of rural development as a result of a revived interest in rural areas on the part of governments, private business, donor agencies, academics, the media and even rural dwellers (World Bank, 2007; BMZ, 2011). There is little doubt about the origin of the new interest in rural regions: it is the result of rising prices for agricultural commodities.
Whether these are seen as a reason for concern or for hope, there is widespread consensus on the nature of the new trends: after three decades of low prices for agricultural producers and two decades of neglect visited on rural regions, the resources of rural areas have become attractive once again. It is generally assumed that world market prices for agricultural commodities - following the extreme price hikes of 2007-2008 and 2011-2012 - will increase further within the foreseeable future (von Braun and Diaz-Bonilla, 2009). This expectation has resulted in a global rush for control of rural resources and markets. While some try to get direct control of land and water, others try to control agricultural commodity chains and local producers. These endeavours towards intensified capitalisation on the part of private business agents are accompanied by debates about the right policies for promoting agricultural production and food security: while some call for a new green revolution based on industrial inputs including Genetically Manipulated Varieties (GMV), others favour intensified and sustainable lowexternal-input technologies. 
Thus, there is a wide range of present-day issues relating to agricultural production and markets which have to be seen in context: food crises, land grabbing, global value chains, agro-based fuel, bio-technology (genetically manipulated crops), climate change, changing rural-urban livelihood patterns and the question of the survival of the peasantry. One thing is certain, rural areas in the global South will not remain unchanged under the new market and environmental dynamics and the resultant social and political dynamics. So we tend to talk about new ruralities ${ }^{1}$ in the global South, while knowing that this is nothing more than a catchphrase indicating some sort of rural transformation.

But what is the exact nature of this change? What are the causing factors, and what are its impacts? What do the new dynamics mean for the 2.5 billion people whose livelihoods depend at least partially on agriculture (World Bank, 2008), and what do they mean for global food security? Will the masses of peasant farmers ${ }^{2}$ be overwhelmed by the investment dynamics and commodity chain mechanisms and lose their access to land as their major basis for survival, or will they get a chance to make the most of the opportunity of higher demand for their products and be able not only to increase their income but also to feed the world? Bearing these questions in mind, this article aims to explore the implications of new global market and environmental dynamics for the rural population, in particular small-scale farmers, in the global South, for their livelihood systems and for food security. The focus on small-scale/peasant farmers is justified by the specific and direct way these actors are affected by market and climate trends, by big land investments and by value chain integration or exclusion. ${ }^{3}$

Taking into account that rural dynamics can be looked upon from a very different perspective, another objective of the article is to contribute to the debate on appropriate theoretical approaches towards analysing the new ruralities.

\footnotetext{
${ }^{1}$ The term new ruralities has been used since the late 1990s to describe a transformation process in rural areas characterised by close interactions with the urban world and by reduced importance of small-scale farming and related patterns of village culture (Cloke, 2005).

${ }^{2}$ The term peasant is used for rural households with access to land (or other natural resources) depending on subsistence agriculture (or fisheries or forest products) as a part of their diversified livelihood system without being fully involved in commercial agriculture and without consistently following a farm enterprise logic (Chayanov, 1966; Shanin, 1987; Akram-Lodhi and Kay, 2009). In this article the term peasant is used if the non-commercial nature of farm households is to be emphasised. The terms smallholders and small-scale farmers (including tenants) are used in a more general way for all rural households that depend to a significant degree on family farming.

${ }^{3}$ People without access to land form a significant part of the rural poor in many countries (especially in Asia). But they are in a different position in relation to the new market and environmental dynamics regarding their ability to respond and their vulnerability.
}

Moreover, the results of the analysis are intended to contribute to the policy debate on the right ways and means of steering and promoting rural and agricultural development, so as to reduce rural poverty and ensure food security.

After this introduction, Sect. 2 will provide a historical perspective on rural development as a basis for a better understanding of present-day dynamics and - with regard to policies and strategies - for learning from experience. Section 3 will provide a short overview of various conceptual approaches towards analysing rural and agricultural dynamics, focussing on approaches which have gained some popularity within the field of geographic development studies. That overview will result in a presentation of the analytical framework underlying this article. In Sect. 4, the core chapter of this paper, the present rural dynamics and their implications for small-scale farmers in particular, will be analysed as a combined result of market, natural, social, political and institutional dynamics. Sections 5 and 6 will deal with the implications and conclusions for geographical research and for rural and agricultural development policies.

\section{Historical perspective: persistence of and change in the peasant mode of production during the post-colonial period}

Since colonial times peasant farmers in Africa, southern and Southeast Asia and Latin America ${ }^{4}$ have - to a greater or lesser degree - been involved in the market economy. Either they produced agricultural surplus for international or domestic markets, or they have been engaged in wage labour as migrants on a seasonal basis or during certain phases of their life cycle, or have become involved in various off-season business activities such as petty trading or petty craftsmanship. All these options have been used in different combinations to satisfy the families' cash requirements resulting from imposed government taxes and from increasing demand for commercial commodities. The degree to which they have been involved in the monetary economy has varied, but hardly any peasant farmer household in the developing countries has abandoned subsistence farming altogether. At least some of the household members have made use of the land (water resources, forest resources) to which they had access based on traditional land use rights, tenancy relations or individual property. These systems were described in academic literature as articulation of modes of production in the 1980s (in German literature known as the Bielefelder Verflechtungsansatz - Elwert, 1985; Evers, 1988). In the 1990s that mode of production received renewed attention from scholars of the sustainable rural livelihood approach, which focussed on the analysis of the phenomenon of diversified livelihood sources and strategies (Chambers and Conway,

\footnotetext{
${ }^{4}$ The historical overview does not apply to post-communist countries with their dominance of collective agriculture which followed a completely different development path.
} 
1992). The underlying macro-economic rationale of interlinking subsistence and market economies with their contradicting logics has been a situation where most families could no longer rely on subsistence production only (as it could not satisfy all needs in a partly commoditised world) nor could they depend on market-related production and wage labour only (as this did not provide sufficient reliable income opportunities for the masses of the people in most countries). Many of the landless people in rural areas are forced to follow similar diversified livelihood strategies in the absence of reliable income sources.

After political independence and since the beginning of developmentalism in the 1950s, most rural areas dominated by the peasant mode of production have passed through two major phases, characterised by the different roles governments and private businesses tried to play in agricultural and rural development (Rauch, 2011).

1. The phase of state-dominated agriculture (before 1990). Governments played a dominant role in providing agricultural services (research, extension, credit, input supply) and in regulating and managing agricultural commodity markets through fixed prices, customs and state marketing boards. At the same time the governments of industrialised countries - the USA and the EU in particular - spent huge amounts to protect and subsidise their own agricultural production, thereby causing surplus supplies and low agricultural prices on the world markets. The way governments made use of their power to promote agriculture differed considerably from country to country. A couple of governments, mainly those in densely populated countries in southern and Southeast Asia (e.g. India, Thailand), embarked on green revolution strategies in order to increase productivity. They managed to provide an effective service package based on high-yielding crop varieties, high amounts of chemical inputs and irrigation, thereby enabling smallholder farmers, or to be precise, those in favourable locations and with better resource endowment, to increase yields dramatically, producing huge surpluses for the markets (Evenson and Collin, 2003; Conway, 1997). However, the majority of governments, mainly in sparsely populated countries and regions (e.g. most of sub-Saharan Africa) and countries endowed with rich mineral resources, being less dependent on agricultural surpluses (e.g. Nigeria; Zambia), used their capacity for market control to favour urban consumers over rural producers by fixing producer prices at low levels and by overvaluing their exchange rate (which made the - already subsidised - products from overseas even cheaper on the local markets). It was this policy of urban bias (Lipton, 1977) together with often poor and unreliable services that discouraged the majority of the peasants from making efforts to produce more surplus for the market than was absolutely necessary for satisfying their ba- sic cash-related needs. At the same time, the growth of non-agricultural employment remained limited and was unable to absorb the growing number of job seekers.

As a consequence, the peasant mode of production based on subsistence farming and partial and unstable market integration remained the dominant mode of production in most of the rural areas of the global South. The vast majority of the peasants remained marginalised - some call it uncaptured (Hyden, 1980) - as a consequence of limited demand and low producer prices.

2. The phase of market- and agro-business-dominated agriculture (from 1990). World-wide efforts towards market deregulation, in combination with structural adjustment programmes in the highly indebted developing countries, aimed at deregulating domestic markets were implemented as a neoliberal response to the problems of inappropriate state control. The market mechanism was expected to provide a solution to all problems, including the depressed state of agriculture in many countries. Foreign exchange rates were adjusted, price control and restrictions on private trade abolished, subsidies were reduced and agricultural services were privatised. The results of the new policy environment were ambiguous: on the one hand, new market opportunities emerged, in export as well as in domestic and local markets. On the other hand, competition between agricultural producers on domestic and export markets intensified, resulting in continuing oversupply and the low-price regime. Moreover, many of the international and the domestic markets became increasingly dominated and controlled by oligopolistic global food empires (Van der Ploegh, 2010) or by local monopolists with strong political patronage. Another new problem from the perspective of peasant farmers was strong seasonal price fluctuations for staple food crops as a result of deregulated prices. Poor peasant farmers often found themselves having to sell part of their produce at the lowest prices right after the harvest because of their urgent need for cash and having to buy food just before the harvest at the highest prices.

The result of these dynamics was selective market integration. Well-resourced farmers at favourable locations were able to take advantage of the new opportunities, while the majority of peasant farmers in peripheral locations with marginal resource endowment suffered even more from the limitations and challenges. Their livelihoods became more vulnerable as a result of unstable market conditions (cf. Heidhues and Obare, 2011 , for their analysis of the effects of structural adjustment programmes on African agriculture). Many of them, in particular young family members, have turned their backs on agriculture and on their villages. As a result, the dependence of those multi-local, rural-urban livelihood systems on urban or foreign income sources 
has increased (Thieme, 2008). Nevertheless, most families also still depend on their access to land for subsistence production as for many of them their external income sources are limited and unreliable.

What can be taken from this story, which is presented here in a very simplified and generalised manner, is that beyond all the agricultural policy changes and regional differences, there has been a remarkable degree of continuity with regard to the peasant mode of production over the last five decades: the system of partial market integration for small-scale farmers has remained as a highly vulnerable but at the same time stable system. The markets - neither agricultural commodity markets nor labour markets - have not been able to offer enough opportunities for farmers to be able to forget about subsistence farming. On the other hand, in a situation of increasing population density and commercialisation, subsistence farming is not able to offer enough food security and needs satisfaction to allow smallholders to withdraw from unattractive, unstable and dependencycreating markets. The end of peasant farming, often announced (Bryceson et al., 2000), has not come about, because there has not been an alternative option suitable to feed billions of rural-based people and as a situation of oversupply has, in general, not stimulated the interest of other players in the resources used by these people. This applies not only to the masses of African smallholders but also to the majority of their fellow Indian, Indonesian or Bolivian farmers, to mention just a few examples. Therefore, even in 2006 it still seemed to be fair to conclude that peasants are condemned to survive (Rauch, 2006). Consequently, one can conclude that in most rural regions it was neither the desire of the peasants to maintain their mostly precarious and marginalised economic situation, nor just the failure of governments to do a better job of integrating them into the markets, nor the scarcity of resources that stopped them doing better. The decisive bottleneck that prevented the large majority of smallholders in many developing countries from achieving successful market integration was rather limited demand going along with unattractive prices. This is the background in relation to which the recent dynamics need to be analysed.

\section{Theoretical perspectives}

The dynamics in rural regions, like developmental dynamics in general, can be analysed from a wide range of different theoretical or analytical perspectives ${ }^{5}$. Before trying to find answers to the questions regarding the nature, the

\footnotetext{
${ }^{5}$ The approaches outlined in this section are not necessarily theories in the sense of consistent models of explanation, but rather different perspectives on and approximations to the issue of rural dynamics.
}

contributing factors and the implications of those dynamics, one should reflect on the appropriate approach for exploring them. The most common contemporary approximations towards analysing rural development, including their merits and their limitations, will be shortly outlined here before reflections on their appropriateness are presented.

1. Global market dynamics/global systems perspective. This macro-systems and structural approach tends to focus on the impact of world market dynamics on the development processes in rural regions, for different population groups or on issues like poverty, food security, growth and income distribution. Examples would include the theory of fragmented development (Scholz, 2002), which says that market dynamics in a deregulated global economy tend to exclude a large share of the world population from participation in the dominant capitalistic production process as well as from its benefits. Another example would be the Marxist perspective, from which the new dynamics could be interpreted as a new stage in the process of capitalistic expansion into regions and spheres so far not yet fully integrated into the logic of capitalist accumulation (Harvey, 2003). Other examples are from the discipline of agricultural economics. They analyse market dynamics in relation to macro-trends that influence supply and demand and their impact on various categories of producers and consumers (von Braun and Diaz-Bonilla, 2009). These approaches, based on different theoretical frameworks and ideological assumptions, have one theme in common: they want to show in which way the opportunities of people to get access to food, jobs and income depend on aggregate global trends in commodity, labour or financial markets. Thereby they help to keep in mind macrolevel factors and their power to set the framework for local action - e.g. limitations regarding the possibility of the full market integration of smallholders on a global scale. These approaches, however, fail to analyse who - which countries, which players, which individuals or communities - is able to make use of limited opportunities and who fails, due to which factors.

2. Global power structures perspective. This approach tends to focus more on agents than on market mechanisms and systems' dynamics. According to this school of thinking, it is the oligopolistic power of food empires (Van der Ploegh, 2010) controlling global agricultural supply and commodity chains who push for the commoditisation and industrialisation of agriculture. In doing so they integrate part of the peasantry into their supply chains; thus increasing their dependency and reducing their resilience, while excluding from the land and the markets all those peasants who do not meet the requirements of the system; moreover, they exercise control over food markets and tend to aggravate price hikes in times of shortages. This perspective is crucial insofar 
as it is not just anonymous market forces but concrete global players who contribute to food crises, exclusion or increased vulnerability. These types of approaches, however, are not sufficient either, as they fail to consider other relevant factors: problems like food crises, for example, cannot be sufficiently explained without considering the lack of purchasing power on the part of the poor and the underlying fragmenting global trends which cause jobless growth. Moreover, to take another example, the strategies of food empires depend on aggregate global market trends, so land grabbing strategies were quite limited before 2007 as long as agricultural demand and prices were comparatively low.

3. Rural livelihoods perspective. This approach, originating from British schools of rural sociology (Chambers and Conway, 1992) has been prominent as an analytical framework among development geographers since the early 1990s (Geiser et al., 2011). It takes a local perspective, focussing on households and communities. Rural development dynamics are predominantly seen as a result of livelihood strategies, assets and vulnerability contexts (Bohle, 1992). Food crises are perceived as a result of a lack of coping capacities and strategies. While external factors are not neglected, they are usually not part of the focus of the analysis. What is crucial about the livelihood approach is its acknowledgement of the role of rural people and their strategies with a gender-differentiated perspective. From a livelihoods perspective, rural people are not just seen as victims of markets and empires. They may respond differently to opportunities and risks depending on their environments and their values. There may sometimes be, for example, peasants who are pushing for a sugar plantation in their region while others are pushing against it. However, the limitations of the livelihood approach are obvious as well (de Haan, 2012; Scoones, 2009; Geiser et al.,2011). Insufficient attention is given to the interlinkages of local livelihoods with regional, national and global dynamics in general and to markets and power relations in particular.

4. Institutional/governance perspective. Institutional approaches (e.g. new institutional economics - North, 1992) tend to look at rural dynamics in the first instance from a property rights and incentives perspective. According to that perspective the answers to questions such as the survival of the peasant mode of production, exclusion or inclusion, or food security are subject to appropriate, accepted and controlled rules governing access to land and other natural resources, public services and markets. Where good governance is able to establish such rules and related control mechanisms in a participatory and democratic manner, people will enjoy a conducive environment for making use of given market opportunities (Deininger, 2011, with regard to land grabbing). While the consideration of institutional arrangements is crucial in order to understand why some people or countries make use of limited opportunities and others do not, the institutional perspective is limited for two reasons: first, it does not explain why economic opportunities are limited on a global scale. Second, it ignores the power relations and the political economy or political ecology which determine which rules and policies are pushed through and actually implemented and enforced and which are not. To take an example: where leading politicians and many customs officials are benefitting from trade with imported rice, there will not be any serious efforts made to set an institutional framework adequate to promote local rice production, in particular if the rice production areas are inhabited by minority groups.

It is obvious that each of the above-mentioned approaches has the capacity to provide relevant insights into an explanation of new rural development dynamics and their impacts. None of them, however, has the capacity to provide a satisfying explanation on its own. Moreover, as a deeper examination will show, these approaches are complementary, not contradicting. Rural development dynamics can only be adequately explained by a multi-dimensional approach which considers the different factors in context (Rauch, 2009).

\section{Multi-dimensional analysis}

To understand the new present-day rural dynamics one has to analyse them in the context of global agricultural market dynamics and the role of global agro-business players, the environmental change including climate change, the local livelihood dynamics during the past two decades, and the institutional and political dynamics of rural governance and agricultural policies (see Fig. 1).

\subsection{Global markets and agro-business players}

After decades of low prices and excessive supply, global agricultural markets and food markets in particular are presently characterised by a situation where demand tends to exceed supply and prices tend to increase. This trend started in 2005 and culminated in critical price hikes in 2007-2008 and again in 2011-2012 accompanied by hunger crises in numerous low-income countries (von Braun and Tadesse, 2012). According to estimates by all food market experts, world market prices will, irrespective of short-term fluctuations, continue to rise within the foreseeable future for the following reasons:

- Peak oil: increasing scarcity of oil will result in higher agricultural prices as it will push up the demand for agro-based energy sources and further increase the prices for oil-based agricultural inputs such as chemical fertilisers, pesticides and fuel (Exner, 2011). 


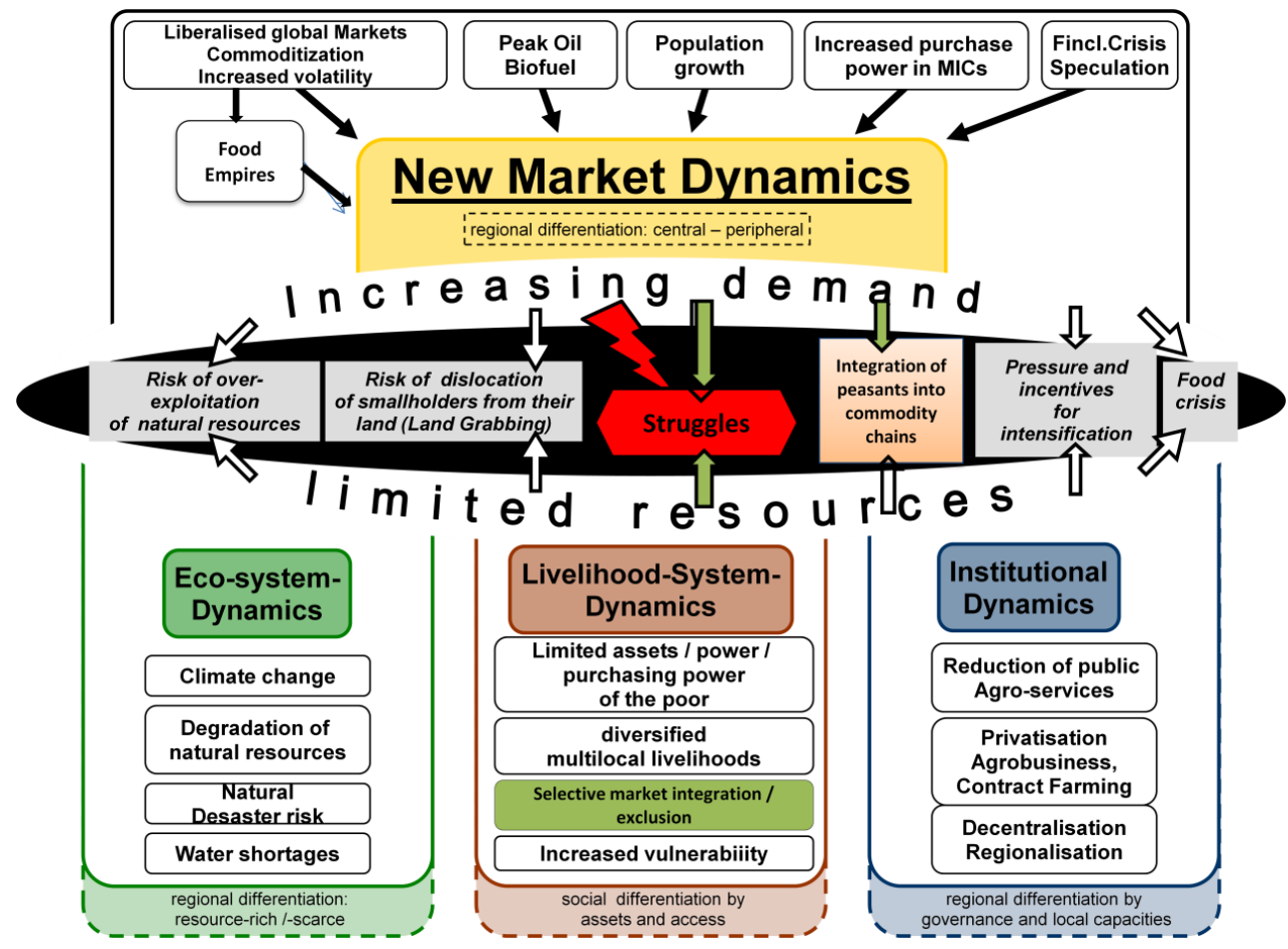

Figure 1. Rural Dynamics from a multi-dimensional perspective.

- Increasing purchasing power of the expanding urban middle classes of densely populated middle-income countries (like China and India): this will result in increasing world market demand for higher value agricultural products such as meat, dairy products, vegetables and fruits.

- Financial crisis: the accumulation of capital in combination with a more and more desperate search for safe and profitable investment opportunities on the one hand and increasingly promising agricultural business opportunities on the other hand will tend to result in investments in land and in food markets becoming increasingly attractive. This will not only lead to speculative exaggerations of price hikes, but will also reinforce the demand-related upward trends of prices (Ouma, 2012).

- On-going population growth will tend to reinforce trends towards accelerating demand for food.

- Liberalised global markets will tend to facilitate these trends insofar as global demand trends as well as the volatility of global markets affect domestic markets in an unfiltered manner.

There is a need for regional differentiation. Even in a globalised world, these general global market forces will not be felt equally everywhere. Their impact is stronger in central regions with open markets than in remote areas with state regulated markets.
Increasing demand with increasing prices might be bad news for the consumers of agricultural commodities. But what about the producers? Should farmers, including peasant farmers, not be happy about better demand and prices for their products? The answer depends on a range of other factors.

\subsection{Natural environment dynamics}

While demand is increasing, natural resources relevant for agricultural production are tending to become increasingly scarce and unreliable. The most broadly discussed, but not necessarily the severest factor, is climate change. Though the precise nature of its impact on agricultural yield is not yet known with a high degree of certainty, there is little doubt that rainfall variability and thus the insecurity of yields is set to increase in tropical and subtropical zones, while agricultural production potentials may improve in parts of the northern latitudes (IPPC, 2007). While it is true that many farmers in the global South are already suffering due to irregular rainfall patterns, in many places the focus is still on other environmental limitations: soil degradation, the depletion of forests including biodiversity and the increasing scarcity of water resources tend to reduce yields or to limit the capacity for expansion of production (Barrow, 2004). Moreover, these trends in combination increase the risk of natural disasters, such as droughts, floods, tropical storms or landslides, thereby aggravating the vulnerability of poor smallholders 
in particular. It is important, however, to keep in mind that there are significant regional and local differences regarding availability of natural resources. While such resources are already severely over-utilised in some places (in particular in densely populated areas of southern and Southeast Asia, northern Africa and the Middle East), there is still considerable scope for the environmentally sustainable expansion of their utilisation in many parts of sub-Saharan Africa and South America.

Nevertheless, it is realistic to conclude that, on a global scale, increasing demand for agricultural products will meet a declining natural basis for their production. Such constellations are not totally new to mankind. They usually call for intensification - understood as an increased amount of product per unit of land or water - which is usually achieved through technological innovation based on more input of either human labour or material means of production. The related question is how are farmers and how are institutions prepared for responding to that challenge?

\subsection{The human factor: livelihood systems dynamics}

As a result of the neglect of rural areas and peasants during the past decades, many smallholder households - or at least some of the household members - had turned their backs on agriculture and on their home villages. But few of them gave up the cultivation of their fields completely (see Sect. 2 above). The well-known result is the emergence of diversified multi-local, rural-urban livelihood systems (e.g. Steinbrink, 2009). Migration and formal education have become important features of most rural livelihood systems (see contributions by Benz in this volume). For young people, in particular, farming was no longer attractive; it became a no future business. Many of them lost interest in the local agricultural knowledge of their forebears. While migrants in general tend to keep close links to their home regions, many of them have lost their agricultural roots and their attachment to the soil. Often it was the women together with the children and elderly family members who stayed back in the villages to care for subsistence fields (see contribution by Bieri). As a consequence, many people are not anymore in a position to respond flexibly to the newly emerging opportunities of producing agricultural surplus and to the related challenge of intensifying cultivation through improved agricultural practices. Either they were not around at all or they did not have the skills to adapt creatively to economic and climate changes. As economists tend to say: they had lost their supply elasticity. Moreover, peasant farmers tend to have limited financial assets and are thus unable to buy external inputs. They have mostly seasonal labour constraints and are thus not prepared to go in for labour-intensive agricultural practices; moreover, in many places land has become a limiting factor for them as well; therefore, they cannot easily extend their cultivated area. Thus, the generalising picture of limited supply elasticity needs to be differentiated by region, liveli- hood system and social strata: resource-rich households will find it easy to mobilise resources to respond flexibly while the masses of resource-poor households will fail to do so.

As a consequence of their increasingly diversified and multi-local livelihood systems, many peasants all over the global South are in a paradoxical situation which can only be understood by considering the historical background and the rationale of diversified livelihood systems: while they were prevented or discouraged in past from making better use of their productive resources by unattractive or inaccessible markets, now many are not well prepared to take up the new market chances arising. The market dynamics have caught them on the wrong foot.

\subsection{The institutional factor: rural governance and agricultural policies}

If the smallholders are in a bad position to respond positively to changing market conditions, then the same can also be said, in general, for those institutions on which farmers usually rely on for their ability to take advantage of economic opportunities: most governments had reduced their involvement in agricultural and rural development after 1990. The same is true for international development partners and publicly funded agricultural research. As young farmers turned their back on agriculture, young students all over the world did the same. As a consequence, world-wide competence on issues related to agricultural and rural development has shrunk drastically within one generation. Whether or not decentralisation has already created a new basis for concerted action by regional players as territorial approaches would suggest remains to be investigated (see contributions by Koop). Rural development has been entrusted to inadequately capacitated local governments on the one hand, and to the commercial interests of private business on the other ${ }^{6}$. As agro-business is highly selective in terms of location, commodity and technology, only some of the smallholders have been in a position to become integrated into agricultural value chains through contract farming arrangements (see Sect. 2). The focus of private services is on specific export crops rather than the intensification of staple food production. It is on improved varieties and high external input technologies rather than on land preparation or water conservation technologies. Thus, the withdrawal of public sector agencies from agricultural research and promotion has left a big gap in many countries which the private sector has only partly and selectively filled. But it is not only the withdrawal of the state from rural regions which created problems. The way government agencies make use of their rule-setting and rule-controlling role is highly determined by rent-seeking strategies. This is especially problematic

\footnotetext{
${ }^{6}$ Rural regions catered for by powerful and well-resourced NGOs like the Aga Khan Foundation are the exception rather than the rule (see contribution of Benz in this volume).
} 
regarding land legislation and utilisation of natural resources like forests or water. Again, this generalising picture needs some differentiation: agricultural policies differ from country to country and local institutional capacities tend to differ from region to region within a country.

\subsection{The factors in context: opportunities and threats}

Briefly summarising the interwoven economic, environmental, livelihood and institutional dynamics, a picture is emerging whereby increasing global demand for agricultural commodities meets not only increasingly limited natural resources, but at the same time a limited capacity to respond on the part of the masses of smallholders and of the institutions which are relevant for supporting them. Increasing supply is meeting limited natural, human and institutional resources. Wherever increased demand comes up against limited or reduced or limited resources, the following types of consequences are to be expected (see Fig. 1):

- increasing prices (in the case of a market economy),

- struggles for access to scarce resources or for control of scarce commodities,

- over-exploitation and degradation of resources,

- innovation (intensification of resource utilisation techniques).

All these consequences are currently found in rural areas of the global South.

First, in 2007-2008, dramatic price hikes for most basic staple food commodities like rice, maize and wheat resulted in a severe food crisis in low-income countries.

Second, as an immediate consequence of increasing prices, various forms of struggles began. In the more sparsely populated regions of sub-Saharan and South American countries a phenomenon widely known as land grabbing, a rush to invest in agricultural land which was regarded as un- or under-utilised has been observed from 2008 onwards. Some of the investors (those from the Gulf area, India and China) were eager to secure access to food or energy in an environment of increasing shortages and an absence of reliable local suppliers. Other investors were not interested in food and agriculture at all, but saw these scarcities as a source of increased profit. So they were eager to acquire control over scarce resources like land or water. The peasant farmers (or herders), as the traditional users of these resources, are often taken by surprise by these dynamics. They mostly have neither the necessary political nor the economic power to triumph in the struggle for their land. Consequently, they are at high risk of losing access to their natural resources or even being dislodged from their resources without being offered a viable economic alternative (see contribution by Locher and Müller-Böker). In more central and densely populated rural regions, where there are enough peasant farmers who are able to respond to the demand and to meet the requirements, the preferred approach of investors seeking to secure access to scarce agricultural resources has been the integration of existing smallholders into value chains. Those farmers have lost some of their independence, but may have gained reliable market access instead (see contribution by Franz).

Third, natural resources, in particular tropical rainforests and soils, are depleted at an accelerated speed by commercial large-scale palm oil, soya bean or beef production units, to mention just a few examples.

While all these struggles for access to land or control over commodity chains are still going on and while natural resources are being further depleted, the fourth option of dealing with shortages, the need for innovation and intensification, is being discussed. Politicians, researchers and agro-business agents are debating the necessity of providing small-scale farmers with the means to increase agricultural productivity as a way to satisfy increasing demand by achieving a higher yield from already existing agricultural land. The opportunity for increasing the productivity and the income level of previously neglected and marginalised peasant farming systems seem to be brighter than ever before:

- there is political pressure for the intensification ${ }^{7}$ resulting from increasing demand and the need of environmental protection,

- there are incentives for intensification formed by increasing producer prices,

- and there is ample space for intensification in many locations.

Consequently, potential for intensification which has not been used before as it did not make commercial sense for the farmers can be now mobilised, if only smallholders can be provided with the necessary means. The controversy is about the appropriate technology to achieve the required intensification: should it be a new green revolution based on high amounts of external inputs or should one go for ecological and labour-intensive ways of increasing productivity with minimum dependency on industrial inputs?

But the struggles are going on, while ways and means of supporting small farmers are still being debated. Unless peasant farmers are not quickly enabled to make use of the opportunities, they will be pushed aside by other more powerful and more flexible players and will ultimately be the losers

\footnotetext{
${ }^{7}$ Intensification is defined as an increase in the production volume per unit of a natural resource (land, water, energy) or per unit of labour used. Intensification can be achieved by labour-, capitalor knowledge-intensive new technologies. Thus, intensification is not necessarily linked to the industrialisation of agriculture in terms of using high amounts of industrial inputs (capital-intensive agriculture). Most practices of sustainable or ecological farming imply intensification too insofar as they result in higher yields based on additional labour or biological inputs.
} 
of a struggle for opportunities which were never there for the taking in the past. The consequences will be increasing landlessness, unemployment and food insecurity for all those people who have neither the cash nor the land to secure their access to food.

\section{Implications for geographical development studies}

In Sect. 3 it was argued that the dynamics in rural regions and the factors contributing to them can only be grasped by a multi-dimensional analysis which considers the different factors in context. The analysis has shown that present-day symptoms like food crises, land grabbing or the integration of smallholders into externally dominated global commodity chains can only be understood if we consider the logics of markets and of farmers, of nature and of institutions. Food crises, for example, cannot be understood without

- analysing the driving forces behind increasing world market demand for agricultural products,

- considering oligopolistic agents who control global food markets and their strategies,

- taking environmental degradation and increasing yield insecurities caused by climate change into account,

- knowing about the implications of multi-local livelihood systems for peasants' capacity to respond to market opportunities,

- knowing about the factors that make peasants unable to cope with extreme seasonal price fluctuations for their staple food crops,

- understanding the rent-seeking attitudes of governments and their related unwillingness to set the rules in a way that guarantees fair access for peasants to resources, services and markets.

Equally, to take another example, we cannot understand the present-day land grabbing hype without

- considering the mechanisms which support a long-term trend of high agricultural prices;

- a certain understanding of financial markets and the market crises which stimulate the search for alternative capital investment opportunities;

- understanding the weakened capacities of peasants to respond to increasing demand (taking into account that for many investors it is not the land as such they are aiming at, but the commodities to be produced on it);

- analysing the weaknesses of and the interests behind rural institutions when it comes to protecting the interests of local land users.
Such multi-dimensional analysis requires theoretical pluralism, rather than academic struggles for the right theoretical perspective on socio-economic processes. The analysis outlined in Sect. 4 has made use of the insights of a wide range of theoretical approaches from different disciplines: you can find elements from world market and globalisation theories, from Marxist accumulation theories, from climate change research, from peasant studies, from livelihood approaches, from the rent-seeking theorem and from new institutional economics schools. The analysis could be enriched by including elements of a discourse- and perception-related perspective. One could call it theoretical eclecticism. Eclecticism, handled consciously, is an answer to the insight that there is not one single perspective, not one big theory with which the world or selected aspects of it can be explained (as proposed already by Altvater, 1987; Rauch, 1996; and Krüger, 2003). Approximations to reality require the issues to be approached from different angles with different analytical tools.

The mix of theoretical approaches needs to be specific to the specific historical and geographic context. For analysing youth unemployment in an old industrialised country with the dominance of formal wage labour, a livelihood approach might be less helpful for a study on under-employment among rural youth in a society where family farming dominates. The same is true for the specific problems of postcommunist transformation countries in contrast to postcolonialist countries. Thus, the argument for a pluralistic theory mix needs to be supplemented by a plea in favour of a context-specific mix.

Whatever the specific mix of theories may be, it will always have to include structural theories as well as agencyfocussed theories. The structural perspective is crucial in order to analyse the dynamics and underlying mechanisms of the framework conditions with which the actors are confronted: that structures, aggregations and generalisations are more than the addition of the individual actions from which they result. The agency perspective is crucial in order to understand the manifold ways different people can respond to and modify the framework conditions (Giddens, 1984). It prevents us from structural determinism (such as saying the peasants are bound to die). While the structural perspective prevents us from methodological individualism (such as assuming that land grabbing is a result of people's increasing greediness). It is the dialectics, the mutual interrelations between structure and agency which can help to understand socio-economic dynamics such as the features of a new rurality.

There are important implications for geography. Most theoretically inspired geographical development studies (at least those done by German-speaking scholars) tend to follow one specific theory which was trendy at that time. In the 1970s much of the work published was written from a dependency perspective. In the 1980s scholars analysed their subjects from an articulation of modes of production 
approach citing sociologists from Bielefeld. From the 1990s onwards the livelihood systems perspective became prominent, while some preferred to look at their subject from a new institutional economics perspective. Many geographers presently like to write their thesis with a handlungstheoretischen (agency-focussed) perspective (for an overview of the history of German Geographical Development Studies see Bohle, 2007; Rauch, 2008). Geographers whose traditional strength is a holistic perspective, but whose traditional weakness was lack of solid theoretical foundation tried desperately to rid themselves of the stigma of being theoretically naked by trying to adopt an appropriate theory from the mainstream of social sciences. In doing so, many of us forgot about our traditional strength of holistic analysis and felt tempted to follow mono-dimensional mainstream trends.

The case of new rural development dynamics presented here shows that geography should instead go for holistic and multi-dimensional analysis. This type of analysis is more appropriate and it corresponds better to the domain of geographers. This does not mean we should go back to a pretheoretical idiosyncratic type of holistic research as was once done by traditional Länderkunde. Rather, holistic analysis with theoretical foundation means

1. knowing the theoretical debates of neighbouring specialised sciences as much as necessary in order to be able to select those tools from the theoretical toolbox which are relevant for the various aspects of the issue under consideration,

2. being able to interrelate the empirical knowledge from the ground and the different theoretical approaches in a context-specific manner.

This proposed role of geographical analysis corresponds to a high degree to the meta-theoretical concept of critical realism, which proposes a dialectical relation between empirical knowledge and theoretical reflection (Danermark et al., 2002). Thereby, theory-based but context-related geographical research will arrive at a much more differentiated picture than provided here in this highly generalising overview contribution.

\section{Policy conclusion}

The analysis has shown that a global situation of increasing agricultural demand against shrinking natural and restricted human and inadequate institutional resources creates an environment which attracts a range of private capitalist and state investors seeking to gain control of either the natural resources or the commodities. It is a situation that calls for the intensification of production in a technical sense and for commercialisation or commodification in an economic sense. There are two principle ways of commercialisation: large-scale industrial high external input agriculture based on landownership taken over by external investors or the integration of smallholders into commodity chains controlled by big agro-business enterprises. If market forces combined with the rent-seeking interest of governments in the global South are allowed to prevail, peasant farmers will disappear or be excluded by being even more restricted to marginal locations than they are now. There will be a smaller group of integrated contract farmers who manage to cope with commodity chain requirements and a large additional crowd of landless people who can at best get jobs as seasonal workers. Only if agricultural policy interventions in favour of smallholders are undertaken with strong international public support, will smallholders have a chance of successful market integration on the basis of strong farmers' organisations and fair publically regulated contracts.

Only through a holistic multi-dimensional analysis of markets, natural resources, livelihoods, political and economic power and institutions is it possible to arrive at context-specific policies which consider the economic, natural, social and political environment.

Edited by: B. Korf

Reviewed by: two anonymous referees

\section{References}

Akram-Lodi, A. H. and Kay, C. (Eds.): Peasants and Globalization: Political Economy, Rural Transformation and the Agrarian Question, London and New York, 2009.

Altvater, E.: Sachzwang Weltmarkt. Verschuuldungskrise, blockierte Industrialisierung ökologische Gefährdung - der Fall Brasilien, Hamburg, 1987.

Barrow, C. J.: Environmental Management and Development, London, 2004.

BMZ: Entwicklung ländlicher Räume und ihr Beitrag zur Ernährungssicherung, BMZ-Strategiepapier, 1/2011.

Bohle, H. G.: Hungerkrisen und Ernährungssicherung, Geographische Rundschau, 44, 78-87, 1992.

Bohle, H. G.: Geographische Entwicklungsforschung, edited by: Gebhardt, H., Glaser, R., Radtke, U., and Reuber, P., Geographie, München, 796-815, 2007.

Bryceson, D, Kay, C., and Mooji, J. (Eds.): Disappearing Peasantries? Rural Labour in Africa, Asia and Latin America, London, 2000.

Chambers, R. and Conway, G.: Sustainable Rural Livelihoods in Practice, Natural Resource Perspectives 42, London, 1992.

Chayanov, A. V.: The Theory of Peasant Economy, Chicago, 1966.

Cloke, P.: Conceptualising Rurality, in: Handbook of rural Studies, edited by: Cloke, P., Mardsen, T., And Mooney, P., 18-28, London, 2005.

Conway, G.: The Doubly Green Revolution, London, 1997.

Danermark, B., Ekström, M., Jakobsen, L., and Karlsson, J. C.: Explaining Society. Critical Realism in the Social Sciences, London, 2002.

de Haan, L.: The Livelihood Approach: A Critical Exploration, Erdkunde, 66, 345-357, 2012.

Deininger, K.: Challenges Posed by the New Wave of Farmland Investment, J. Peasant Stud., 38, 217-247, 2011. 
Elwert, G.: Überlebensökonomie und Verflechtungsanalyse, Zeitschr. f. Wirtschaftsgeographie, 29, 73-84, 1985.

Evenson, R. E. and Collin, D.: Assessing the Impact of the Green Revolution 1960 to 2000, Science, 300, 758-762, 2003.

Evers, H.-D.: Subsistenzproduktion, Markt und Staat. Der sogenannte Bielefelder Verflechtungsansatz, in: Geographische Entwicklungsforschung im interdisziplinären Dialog, edited by: Leng, G. and Taubmann, W., 131-143, Bremen, 1988.

Exner, A.: Die neue Landnahme an den Grenzen des fossilen Energieregimes. Tendenzen, Akteure und Konflikte am Beispiel Tansanias, Peripherie, 124, 470-496, 2011.

Geiser, U., Müller-Böker, U., Shahbaz, B., Steinmann, B., and Thieme, S.: Towards an Analytical Livelihoods Perspective in Critical Development Research, Geographica Bernensia, Bern, 313-330, 2011.

Giddens, A.: The Constitution of Society. Outline of the Theory of Structuration, Cambridge, 1984.

Harvey, D.: The "New" Imperialism: Accumulation by Dispossession, in: Socialist Register 2004: The Imperial Challenge, edited by: Panitch, L. and Gindin, S., 63-87, London, 2003.

Heidhues, F. and Obare, G.: Lessons from Structural Adjustment Programmes and their Effects in Africa, Journal of International Agriculture, 1, 55-64, 2011.

Hoering, U.: Die Wiederentdeckung des ländlichen Raumes als Beitrag zur kapitalistischen Krisenlösung, in: Im finanzmarktdominierten Kapitalismus, edited by: Demirovic, A., Dück, J., Becker, F., and Bader, P., VielfachKrise, 11-128, Hamburg, 2011.

Hyden, G.: Beyond Ujamaa in Tanzania. Underdevelopment and an Uncaptured Peasantry, London, 1980.

IPPC: Climate Change 2007. Synthesis Report. Summary Report. An Assessment of the Intergovernmental Panel on Climate Change, Geneva, 2007.

Krüger, F.: Handlungsorientierte Entwicklungsforschung - Trends, Perspektiven, Defizite, Petermann. Geogr. Mitt., 147, 6-15, 2003.

Lipton, M.: Why the Poor Stay Poor: A Study of Urban Bias in World Development, Canberra, 1977.

North, D. C.: Institutionen, institutioneller Wandel und Wirtschaftsleistung. - Die Einheit der Gesellschaftswissenschaften, Tübingen, 1992.
Ouma, S.: Land Grabbing, in: Ortsregister. Ein Glossar zu Räumen der Gegenwart, edited by: Marquardt, N. and Schreiber, V., Frankfurt a. M., 2012.

Rauch, Th.: Ländliche Regionalentwicklung im spannungsfeld zwischen weltmarkt, Staatsmacht und kleinbäuerlichen Strategien, Saarbrücken, 1996.

Rauch, Th.: Zum Fortbestehen verurteilt. Kleinbauern in Ländern des Südens im Globalisierungsprozess, Geographische Rundschau, 12, 46-53, 2006.

Rauch, Th.: Geographische Entwicklungsforschung. Zum Umgang mit weltgesellschaftlichen Herausforderungen, in: Umgang mit Risiken, edited by: Kulke, E. and Popp, H., Berlin and Bayreuth, 203-219, 2008.

Rauch, Th.: Entwicklungspolitik. Theorien, Strategien, Instrumente, Braunschweig, 2009.

Rauch, Th.: Fundamentals of African Agriculture, Quarterly Journal of International Agriculture, 1, 9-28, 2011.

Scholz, F.: Die Theorie der "Fragmentierenden Entwicklung", Geographische Rundschau, 54, 6-11, 2002.

Scoones, J.: Livelihood Perspectives and Rural Development, J. Peasant Stud., 36, 171-196, 2009.

Shanin, T. (Ed.): Peasants and Peasant Societies: Selected Readings, 2nd Edition, London, 1987.

Steinbrink, M.: Leben zwischen Stadt und Land: Migration, Translokalität und Verwundbarkeit in Südafrika, Wiesbaden, 2009.

Thieme, S.: Sustaining Livelihoods in Multi-local Settings: Possible Theoretical Linkages Between Transnational Migration and Livelihood Studies, Mobilities, 3, 51-71, 2008.

Van der Ploegh, J. D.: The Food Crisis, Industrialized Farming and the Imperial Regime, J. Agrar. Change, 10, 98-106, 2010.

von Braun, J. and Diaz-Bonilla, E.: Globalization of Food and Agriculture and the Poor, Oxford, 2009.

von Braun, J. and Tadesse, G.: Global Food Price Volatility and Spikes: An Overview of Costs, Causes, and Solutions. ZEFDiscussion Papers on Development Policy 161, Bonn, 2012.

World Bank: Agriculture for development, World Development Report 2008, Washington D.C., 2007. 